\title{
Long run growth, convergence and factor prices
}

Citation for published version (APA):

Verspagen, B. (1998). Long run growth, convergence and factor prices. MERIT, Maastricht Economic Research Institute on Innovation and Technology. MERIT Research Memoranda No. 018 https://doi.org/10.26481/umamer.1998018

Document status and date:

Published: 01/01/1998

DOI:

10.26481/umamer.1998018

Document Version:

Publisher's PDF, also known as Version of record

\section{Please check the document version of this publication:}

- A submitted manuscript is the version of the article upon submission and before peer-review. There can be important differences between the submitted version and the official published version of record.

People interested in the research are advised to contact the author for the final version of the publication, or visit the DOI to the publisher's website.

- The final author version and the galley proof are versions of the publication after peer review.

- The final published version features the final layout of the paper including the volume, issue and page numbers.

Link to publication

\footnotetext{
General rights rights.

- You may freely distribute the URL identifying the publication in the public portal. please follow below link for the End User Agreement:

www.umlib.nl/taverne-license

Take down policy

If you believe that this document breaches copyright please contact us at:

repository@maastrichtuniversity.nl

providing details and we will investigate your claim.
}

Copyright and moral rights for the publications made accessible in the public portal are retained by the authors and/or other copyright owners and it is a condition of accessing publications that users recognise and abide by the legal requirements associated with these

- Users may download and print one copy of any publication from the public portal for the purpose of private study or research.

- You may not further distribute the material or use it for any profit-making activity or commercial gain

If the publication is distributed under the terms of Article $25 \mathrm{fa}$ of the Dutch Copyright Act, indicated by the "Taverne" license above, 


\title{
Long Run Growth, ConvergenCe AND FaCtor Prices
}

\author{
By Bart Verspagen*
}

Second draft, July 1998

* Eindhoven University of Technology, Faculty of Technology Management, and MERIT, University of Maastricht. Email: bart.verspagen@merit.unimaas.nl, web: http://meritbbs.unimaas.nl/verspagen.html

I thank Angus Maddison for stimulating me to write this paper, and for useful comments. The views expressed and possibly remaining errors are mine, however.
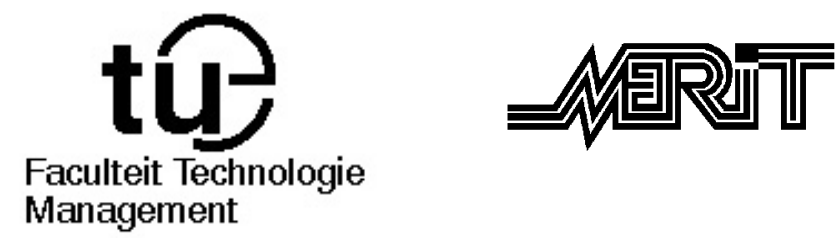

Management 


\section{Introduction}

Long run convergence of GDP per capita levels has been a subject of study in many of the recent and not so recent work on economic growth. One strand of literature, based on the work of Gerschenkron (1962), argues that international diffusion of technology is a major source of convergence in the long run. The argument here is that GDP per capita can be considered as an, admittedly crude, indicator of productivity, and hence as an indirect indicator of the average technological level of a country. Those countries with a relatively low GDP per capita may exploit the backlog of knowledge applied in the technologically leading nations, under the condition that they have adequate 'social capability' and that a minimum level of 'technological congruence' exists between the leaders and followers (Abramovitz, 1986, Fagerberg, 1994).

A different theoretical explanation for long run convergence in GDP per capita comes out of the traditional neoclassical growth model (Solow, 1956, Solow, 1970). In this framework, convergence occurs because all countries are assumed to behave according to an identical production function and can use the same (exogenous) technological knowledge. The neoclassical model based on these assumptions predicts that all countries will converge to a steady state growth path (determined only by population growth and the growth of exogenous technology). The economic mechanism that ensures this convergence is the declining marginal productivity of capital, which gives relatively backward (in terms of the capital labour ratio) countries a growth bonus over the more advanced countries.

In almost all of the empirical studies in these traditions, GDP (or GNP) is used as the basic indicator of economic growth. Williamson (1995) questioned this indicator, and argued that 'factor prices generally, and real wages specifically, are the better yardstick for assessing sources of long run convergence' (p. 142). The reasons for this are fourfold (Williamson, 1995, p. 1423). First, Williamson's interest seems to be in marginal productivity of production factors, and average labour productivity is not a good indicator for this. Note that, given the distinction between different theoretical approaches to convergence (as outlined above), the focus on marginal productivity is typically associated with the neo-classical growth model (or, in fact, with trade theory, as will be outlined below). Second, the deflators for GDP and wages differ, and Williamson considers the one for wages more relevant for measuring 'convergence'. Third, international and intertemporal differences in labour participation rates cause a difference between per capita and per employee (per hour) measures, where the per employee (or per hour) measure is a better indicator of (average) productivity.

Williamson's reasoning in terms of marginal productivity and factor prices thus seems to be biased towards a neo-classical interpretation of growth. In the 'old' neoclassical growth model (Solow), the marginal product of labour depends on the exogenous state of technology as well as the capital labour ratio. In the long run, a country is predicted to converge to a fixed steady state capital labour ratio, which depends on the savings rate. Convergence in this model is thus conditional on the savings rate (see Barro and Sala-i-Martin, 1995). If convergence takes place 
(e.g., when savings rates are equal across countries), this implies convergence in term of GDP per capita as well as in terms of (real) wages. It would thus not make a large difference whether one would test in terms of marginal productivity (or wages) or average productivity. However, the wage side of the issue is not often tested (Dollar and Wolff, 1993, is a notable exception).

However, a different perspctive on the issue is provided by the theory of international trade. In the traditional (static) trade theory (HOS), factor price equalization results from international trade under the assumption that production technologies are the same across countries, but factor endowments differ. ${ }^{1}$ The HOS model, however, does not have the same implications as the Solow growth model for convergence of productivity (see Dollar and Wolff, 1993, pp 47ff for a more elaborate treatment). In the HOS model, factor price equalization resulting from international trade leads to equal levels of labour productivity on an industry-by-industry base, but not necessarily so at the aggregate level. The reason for a lack of convergence at the aggregate level lies in the fact that different countries may be characterized by different sectoral shares in production, and each sector has its own capital labour ratio. The different sectoral shares in production result from trade specialization, which in turn is a function of factor endowments (capital labour ratio). Thus, where the Solow growth model predicts convergence in labour productivity and wages at (approximately) the same rate, the HOS trade theory predicts complete convergence in wages, but incomplete convergence of labour productivity at the macro level. Williamson's (1995: 143) assessment that "wage convergence is likely to be far more dramatic than GNP per worker convergence" seems to be rooted in this 'trade approach' to convergence.

The, often less formal, approaches in the field of economic history, institutional economics, cliometrics or 'technology gap' theories, in general do not arrive at such a clear-cut relation between convergence in wages and productivity. In the tradition of rather complex and multicausal interpretations of all these frameworks, a multitude of factors would be considered to have an impact on wage formation. Although, as stressed by Williamson, work on the relation between growth and labour markets is relatively underdeveloped in these theoretical frameworks, there is no reason to expect a priori that a strong correspondence between convergence in GDP per capita and real wage rates will result.

Concluding, a comparison between convergence in GDP per capita and real wages is an interesting issue. From a neo-classical point of view, one may distinguish between two perdictions: the 'trade based prediction' argues that real wages converge more rapidly than GDP per capita, while the growth theory predicts no difference in the speed of convergence between the two. However, despite Williamson's implicit comparisons of his own results to the empirical results based on GDP per capita, he fails to compare the two indicators explicitly. It is the aim of this paper to fill this gap by systematically comparing the data on GDP per capita from Maddison (1995) and those on real wage rates from Williamson (1995). In doing so, the 'stylized facts' that

\footnotetext{
${ }^{1}$ In order to prove factor price equalization from the model's assumptions, it is necessary to assume that 'factor intensity reversals' do not occur (see, e.g. Leamer (1984), chapter 1).
} 
a theory on convergence of GDP per capita and real wage rates will have to explain will be outlined, and some comments upon the usefulness of the above mentioned theories in light of the comparison carried out will be made. Also, some ad hoc speculations about the observed trends in the data will be provided.

\section{A comparison of trends in real wages and GDP per capita}

In comparing the data on real wages from Williamson to the GDP per capita data from Maddison, one has to keep in mind the methodological differences between the two data sets. Maddison's data are based on national accounts definitions, and include all economic activities defined in this framework. As such, the GDP per capita data by Maddison (as used in this paper) refer to a constant set of economic activities for the complete period which is covered. Obviously, the quality of the GDP data vary with the periods and country for which they are estimated.

Williamson's data, on the other hand, refer to a specific group of workers ("typically urban unskilled", p. 142) only, and this sample, in many cases, does not seem to be representative for labour income as a whole, let alone income from non-labour sources. Moreover, the sample of workers to which the wage data by Williamson refers, differs over time (e.g., after 1950, Williamson uses primarily wages in manufacturing from ILO and OECD sources, before 1950 the sample is considerably smaller in many cases), and no attempt seems to have been made to correct the data for this. Also, changes in social security benefits or payments are not taken into account when constructing the data, nor is the impact of overtime and bonuses (i.e., Williamson's data are pure wages rather than total earnings). The Williamson wage data can thus only be seen as a very crude approximation of trends in labour income.

Given this background to the data, the relation between the growth of GDP per capita and real wages at the country level is investigated. To this end, Maddison's data on GDP per capita in 1990 Geary Khamis dollars, were expressed as the level in $1900=100$. These results are then compared to the data in Williamson's Table A1.1 ('national real wage indices, $1900=100$ '). ${ }^{2}$ The results, for 17 countries, are displayed in Figure 1. The graphs contain periods for which a linear interpolation on the log scale (i.e., a straight line was drawn between the adjacent points in the graph) was made for missing data (especially for the early GDP data, which is available only for key years for some countries, and for the periods around the world wars, for which real

\footnotetext{
${ }^{2}$ Williamson's Table A2.1 (International real wages) contains data for more years than in Table A1.1, despite the fact that Table A2.1 has been calculated on the basis of Table A1.1. We therefore calculated the data for those missing years from Table A2.1.
} 
Figure 1. Long-run movements in wage rates (thin line) and GDP per capita (thick line), value for 1900 $=100$
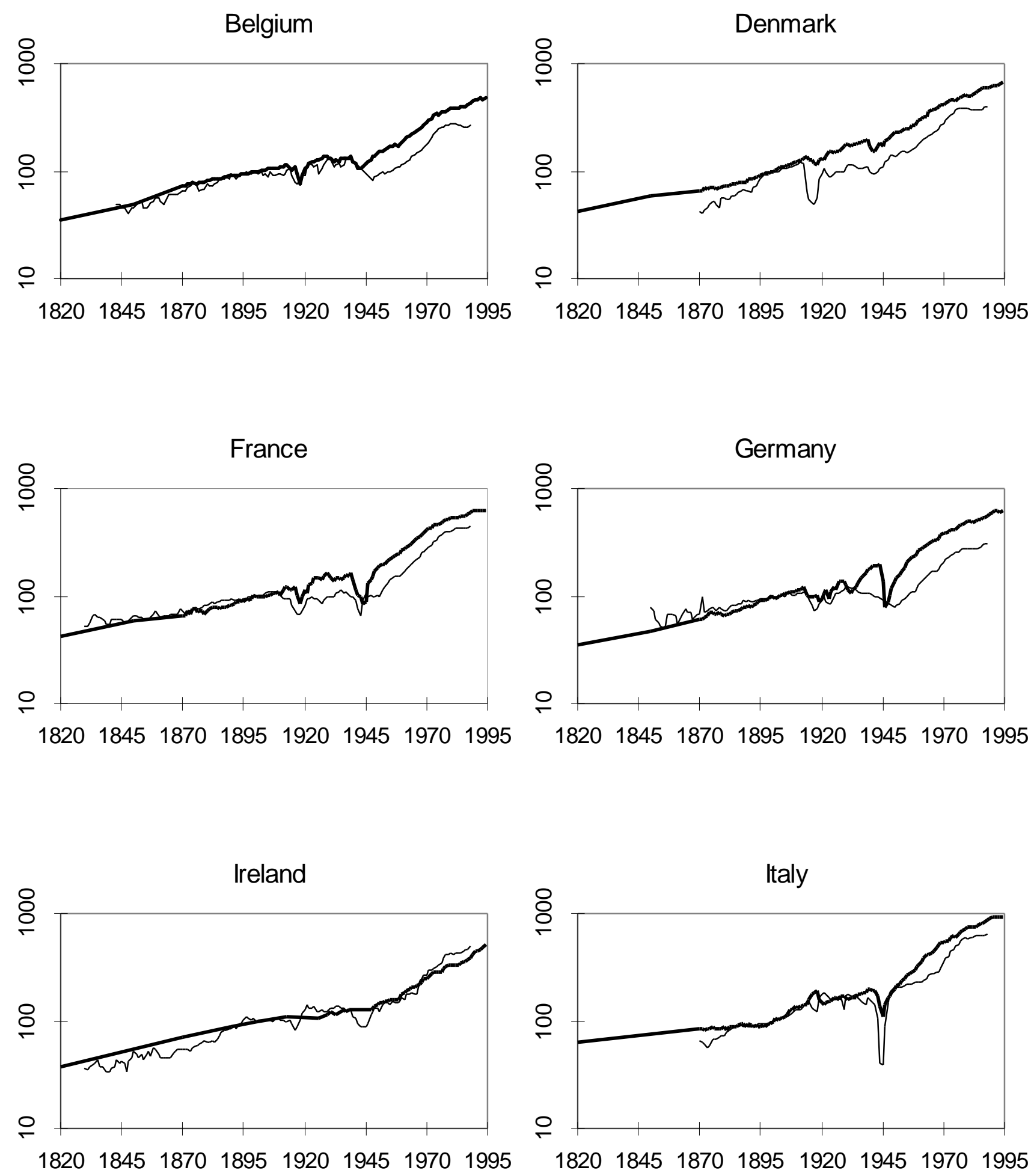
Figure 1. Long-run movements in wage rates (thin line) and GDP per capita (thick line), value for 1900 $=100$ (continued)
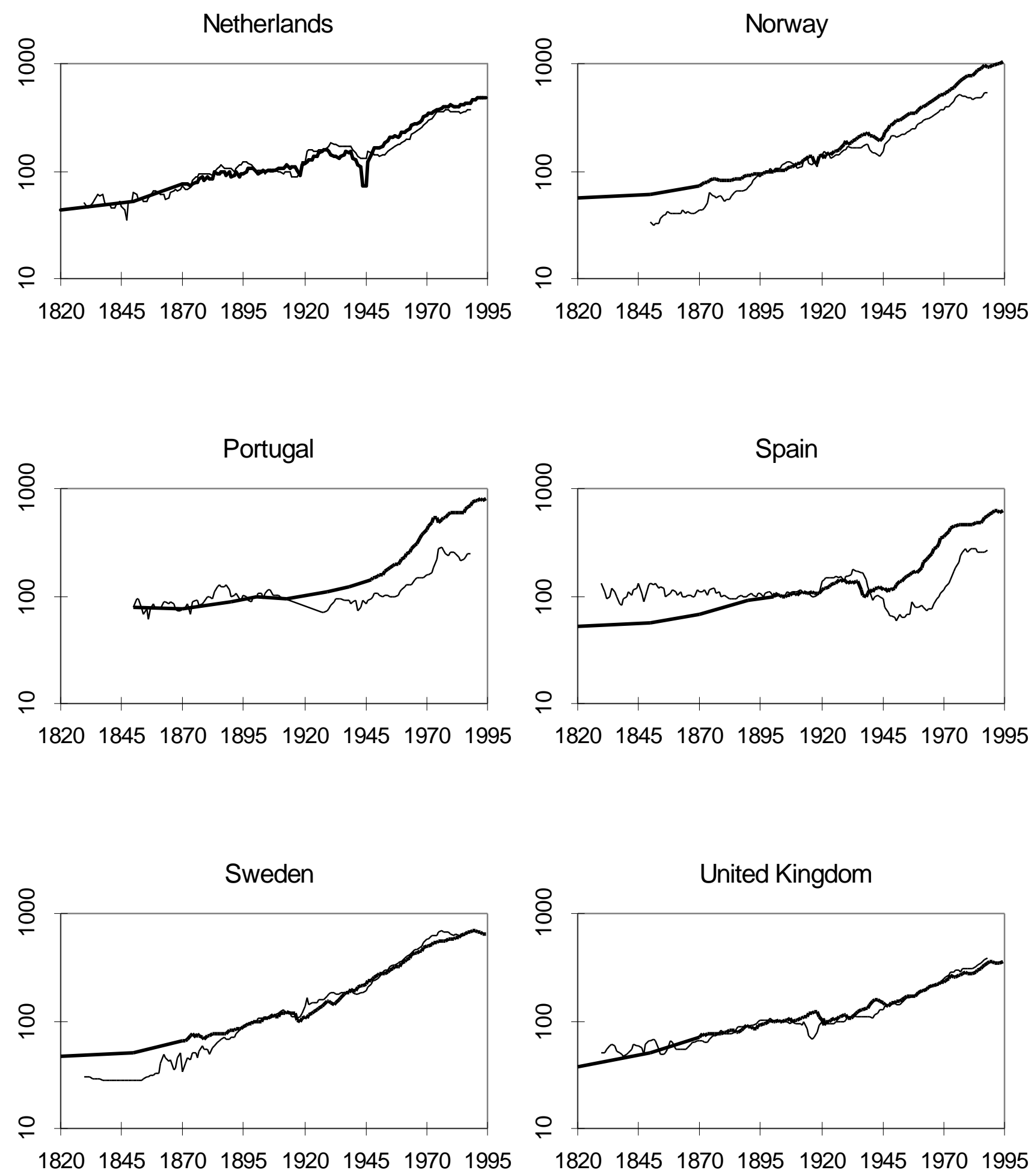
Figure 1. Long-run movements in wage rates (thin line) and GDP per capita (thick line), value for 1900 $=100$ (continued)
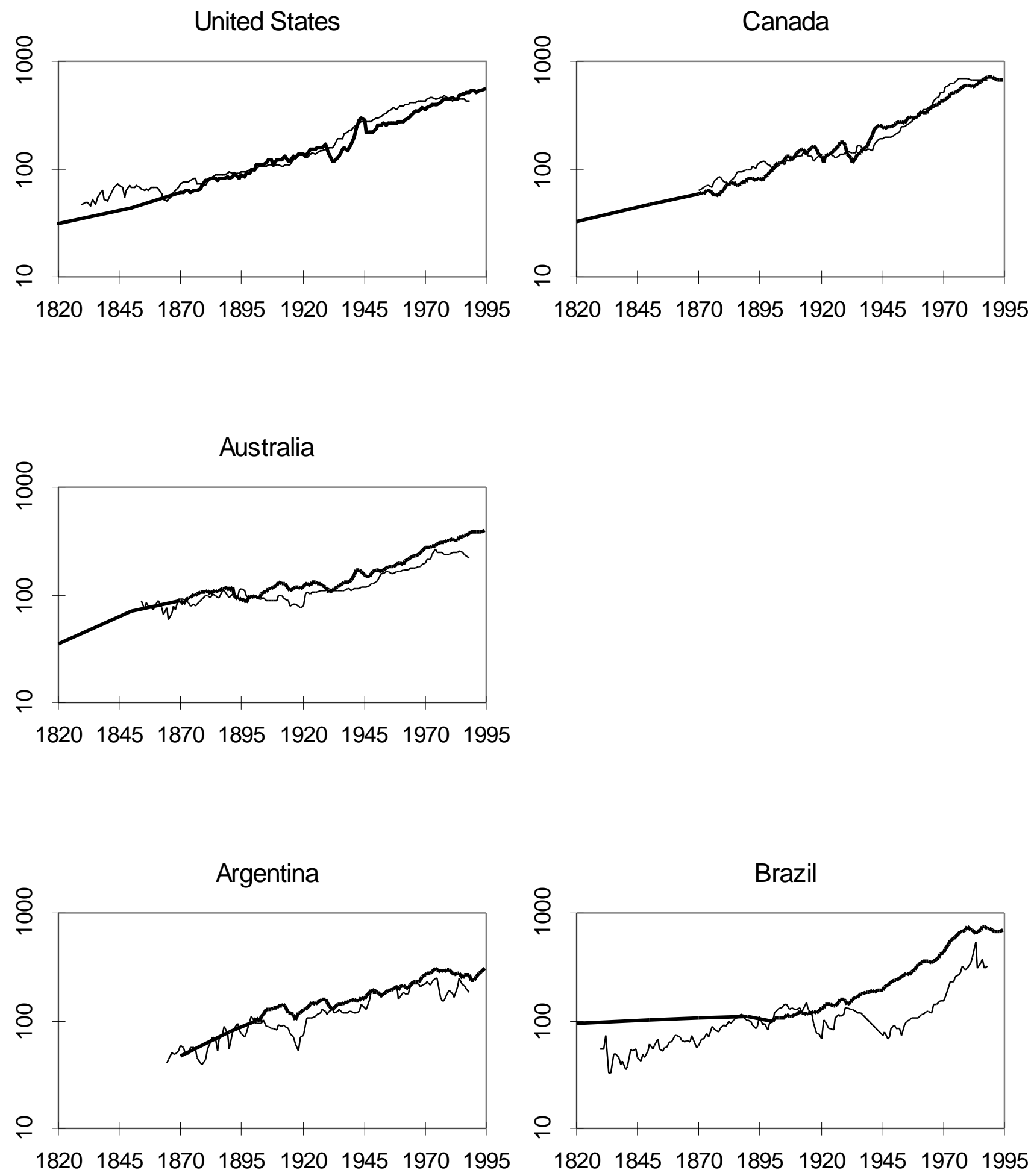
wage data are often lacking). It also contains the breaks in the Williamson data. ${ }^{3}$

The typical pattern in Figure 1 is one in which the lines for real wages and GDP per capita are close together until they diverge in the period between the two World Wars or directly after World War II. The two lines stay apart at roughly the same distance in the post-World War II period until the mid-1970s. From this time on, in many but not all cases wages start to flatten out, while GDP per capita keeps growing (although at a reduced rate). This causes the gap between the two lines to increase from the mid-1970s onwards. Such a pattern is found Belgium, Brazil, Denmark, France, Germany, Italy, the Netherlands (where the distance between the two lines is relatively small), Norway, Portugal, Spain, and Australia. For four of the five countries (all except Germany) for which there is a break in the wage data series, the divergence between the two lines occurs exactly at this breakpoint, which makes the exact timing of the divergence as indicated by the graphs a bit unreliable in these cases.

Of the eleven countries with this standard pattern, there are nine European countries. Among the six countries for which this 'standard pattern' does not hold, there are three European ones. One might thus argue the 'standard pattern' described above is in fact a 'European pattern'. In Europe, the countries with a non-standard pattern are Ireland and the United Kingdom, where the lines for real wages and GDP per capita remain very close together for the complete period, and Sweden, where the lines are apart until 1900 and move closely together afterwards. Outside Europe, one finds Argentina, Canada and the United States with 'non-standard' patterns. In the United States, the pattern is reverse to the standard pattern, with the line for wages above the one for GDP per capita for most of the postwar period. Canada is a mixed case, with wages lagging behind GDP per capita from 1945 until the mid-1960s, and GDP per capita lagging behind wages afterwards. With regard to the most recent period, a widening gap is seen between the wage and GDP per capita lines in Belgium, Denmark, Italy, the Netherlands, Norway, Portugal, Spain and Australia, but not so in the other countries.

Table 1 provides a slightly different comparison of the trends in wages and GDP per capita. For four different periods, the table gives average annual growth rates per country. The table confirms the visual impression from the graphs that the period 1950 - 1973 is the one characterized by most rapid growth, both in terms of wages and per capita GDP. In the interwar period and the period after 1977, the differences between the growth of wages and per capita GDP is largest, something which is again consistent with the earlier interpretation from the graphs.

Table 1 also gives correlation coefficients between the two growth rates. These results (normal and rank correlation) indicate that overall, the correlation between wage growth and GDP per capita growth is not very high, the values of the coefficients are never larger than 0.5 , although they are all positive, as expected. The correlations are relatively low for the period before 1913 .

\footnotetext{
${ }^{3}$ Belgium: value for $1939=133$, no data for $1940-1946$, value for $1947=86$. Brazil: value for $1937=114$, no data for $1938-1945$, value for $1946=74$. Denmark: value for $1913=118$, value for $1914=62$. Germany: value for $1943=100$, no data for $1944-1949$, value for $1950=78$. Portugal: value for $1912=94$, no data for $1913-1926$, value for $1927=70$.
} 
Rather than a true indication of little cross-country correlation between wage growth and GDP per capita growth, this might be the effect of relatively large measurement errors for the data on the previous century. For 1950 - 1973, the 'golden age', the correlation is also somewhat lower than for the two other periods.

Table 1. Average Annual compound growth rates of real wages and GDP per capita

\begin{tabular}{|c|c|c|c|c|c|c|c|c|}
\hline \multirow[b]{2}{*}{ Belgium } & \multicolumn{2}{|c|}{$\begin{array}{l}1870-1913 \\
\text { wages GDP pc }\end{array}$} & \multicolumn{2}{|c|}{$\begin{array}{l}1913-1950 \\
\text { wages GDP pc }\end{array}$} & \multicolumn{2}{|c|}{$\begin{array}{c}1950-1973 \\
\text { wages GDP pc }\end{array}$} & \multicolumn{2}{|c|}{$\begin{array}{c}\text { 1973-1988 } \\
\text { wages GDP pc }\end{array}$} \\
\hline & 1.1 & 1.0 & -0.3 & 0.7 & 3.9 & 3.5 & 1.2 & 1.9 \\
\hline Denmark & 2.4 & 1.6 & 0.4 & 1.6 & 4.0 & 3.1 & 1.2 & 1.8 \\
\hline France & 0.6 & 1.5 & 0.1 & 1.1 & 5.2 & 4.0 & 2.1 & 1.8 \\
\hline Germany & 1.1 & 1.6 & -0.9 & 0.3 & 5.0 & 5.0 & 1.8 & 1.9 \\
\hline Ireland & 1.4 & 1.0 & 0.7 & 0.7 & 3.8 & 3.1 & 3.1 & 2.1 \\
\hline Italy & 1.7 & 1.3 & 1.1 & 0.8 & 3.5 & 5.0 & 2.3 & 2.6 \\
\hline Netherlands & 0.8 & 0.9 & 1.0 & 1.1 & 3.6 & 3.4 & 0.9 & 1.3 \\
\hline Norway & 2.5 & 1.3 & 1.4 & 2.1 & 2.9 & 3.2 & 1.8 & 3.3 \\
\hline Portugal & & 0.5 & & 1.2 & 2.3 & 5.7 & 2.1 & 1.7 \\
\hline Spain & 0.0 & 1.2 & -1.5 & 0.2 & 3.7 & 5.8 & 4.2 & 1.7 \\
\hline Sweden & 3.0 & 1.5 & 2.0 & 2.1 & 4.1 & 3.1 & 0.6 & 1.7 \\
\hline United Kingdom & 0.9 & 1.0 & 1.1 & 0.8 & 3.0 & 2.5 & 2.0 & 1.9 \\
\hline United States & 0.9 & 1.8 & 2.8 & 1.6 & 1.9 & 2.4 & -0.4 & 1.7 \\
\hline Canada & 1.9 & 2.2 & 1.0 & 1.4 & 5.0 & 2.9 & 0.4 & 2.5 \\
\hline Australia & 0.0 & 0.9 & 0.9 & 0.7 & 2.6 & 2.4 & -0.3 & 1.7 \\
\hline Argentina & 0.9 & 2.5 & 2.2 & 0.7 & 0.6 & 2.1 & -1.3 & -0.7 \\
\hline Brazil & 1.9 & 0.3 & -0.9 & 1.9 & 4.1 & 3.8 & 2.3 & 1.8 \\
\hline Mean & 1.3 & 1.3 & 0.7 & 1.1 & 3.5 & 3.6 & 1.4 & 1.8 \\
\hline Correlation* & & 0.11 & & 0.43 & & 0.34 & & 0.48 \\
\hline Rank correlation & & 0.23 & & 0.45 & & 0.35 & & 0.33 \\
\hline
\end{tabular}

* Correlation between growth rate of real wages and GDP per capita across countries

Source: Williamson (1996, Table A1.1) and calculations on the data from Maddison

The ratio of the real wage rate (nominal wages deflated by the consumer price index) and real GDP per capita can be written as

$$
\frac{P^{c p i}}{P^{g d p}} \frac{N}{P O P} \frac{L}{N} \frac{1}{\sigma},
$$

where $P^{c p i}$ and $P^{g d p}$ are the price indices for consumer expenditures and GDP, respectively, $N$ is the labour force, $P O P$ is population, $L$ is employment, and $\sigma$ is the share of wage income in GDP. Thus, the ratio between the real wage rate and real GDP per capita can be written as the product 
of four variables: the ratio of consumer prices and economy-wide prices, the participation rate (crudely defined as $N / P O P)$, the employment rate ( $L / N$, i.e., 1 - the unemployment rate), and the inverse of labour share in GDP. Any divergence in the ratio of real wages to real GDP per capita is thus to be explained in terms of these four variables.

The variables in the above decomposition can in principle be measured in a national accounts framework. This makes it possible to decompose the divergence or convergence trends between GDP per capita and wages in Figure 1 into different factors. However, data on all the necessary variables are only available for the period 1960 - 1988, and for a limited set of 12 countries. For these countries, data on the two price indices and the share of wage income in GDP was taken from the OECD national accounts publication, while data on population, the labour force and unemployment was taken from Maddison (1991).

The decomposition of the growth rate of the ratio of GDP per capita and the wage rate is documented in Table 2. ${ }^{4}$ The column 'growth (SNA)' in Table 2 gives the growth rate of the GDP/wage ratio as calculated from the national accounts data (Maddison and OECD). The column 'growth' gives the growth of the ratio as observed by comparing the Maddison and Williamson data (Figure 1). The table shows that there are indeed large differences between the two methods (column 'discrepancy'). These must be attributed to differences between Williamson's methodology and the SNA framework used in Table 2 (and by Maddison's GDP data).

Thus, for example, the data on wages in the SNA framework (OECD) are for all labour in the economy, whereas Williamson's data refer only to a limited sample of labour. Also, the price indices used to deflate wages may be different (the implicit consumer price index from the OECD national accounts in Table 2, whereas Williamson does not document his deflators).

Nevertheless, there is a positive correlation between the 'growth' and 'growth (SNA)' columns in Table 2: 0.45 and 0.54 for 1960-73 and 1973-88, respectively. This indicates that although the absolute magnitude of the growth rate differential between Maddison's GDP per capita and Williamson's real wage is not very well explained by the calculations in Table 2 , the cross-country variation is, to a certain degree, explained.

With regard to the underlying factors for the differential trends in wages and GDP per capita, Table 2 points out that there are quite different factors at work for different periods. For 19601973 , both the 'growth' and 'growth (SNA)' columns find that wages grow more rapidly than GDP per capita. The main two factors driving this are an increase in wages as a share of GDP (i.e., wages growing rapidly), and a price effect (i.e., the consumer price index grows relatively

\footnotetext{
${ }^{4}$ In discrete time, the growth rate of a variable $x=a b$ is equal to the sum of the growth rates of $a$ and $b$ plus the product of these two growth rates. The latter is termed the interaction effect, and is usually small (for obvious reasons). In the present case, the variable to be decomposed is the product of four separate variables, in which case there are 11 interaction terms. The sum of these is documented in the table under the column 'interactions'. As can be seen, it is usually small as compared to the other factors.
} 


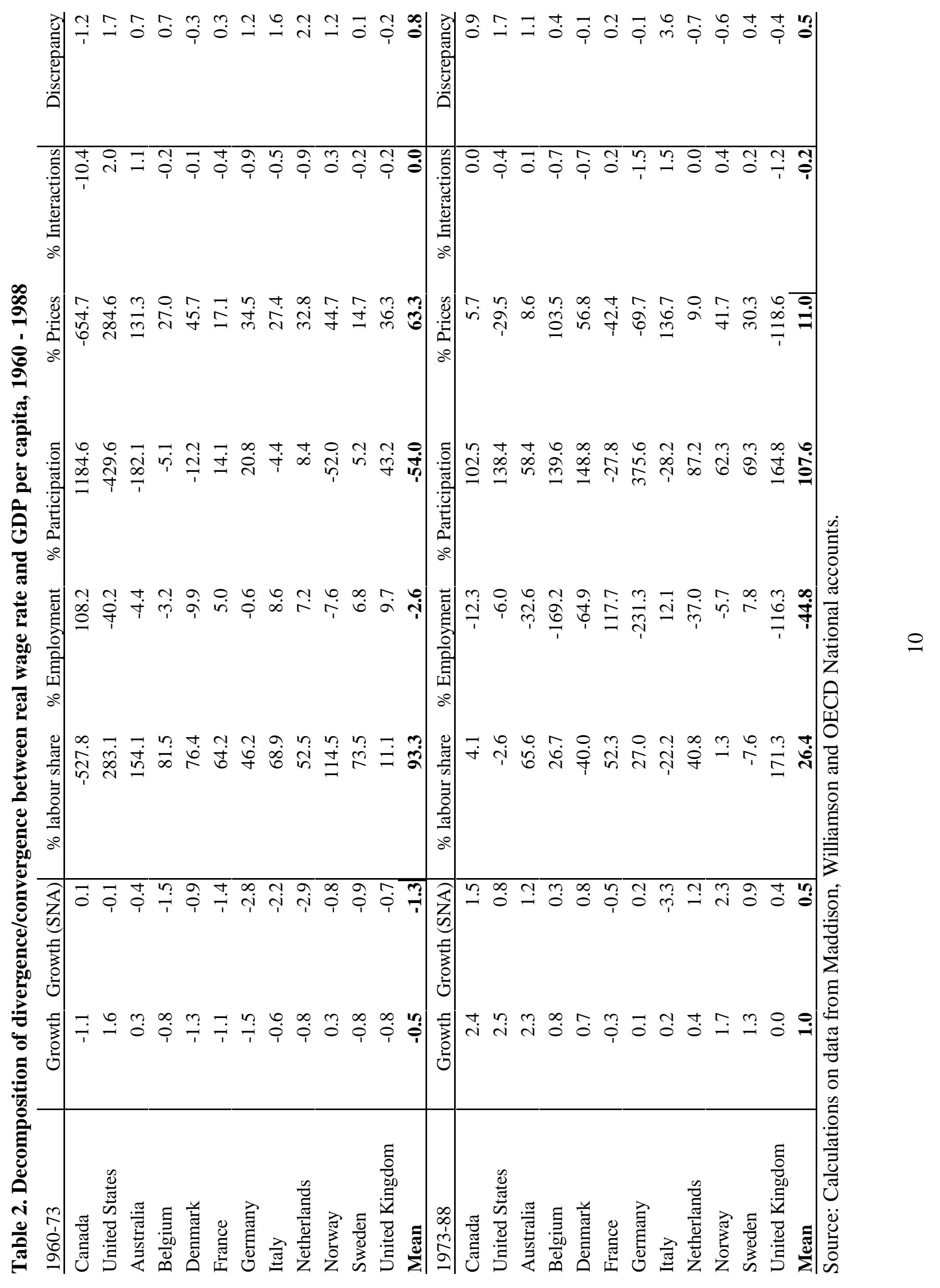


slow as compared to other components of GDP). The main factor that works for equalization (i.e., 'bringing GDP per capita growth closer to wage rate growth') is an increase in the participation rate.

In the 1973-1988 period, on the other hand, GDP per capita grows more rapidly than wages. The participation rate, which continues to rise, is the main explanation behind this trend. Rising unemployment is the main factor that works against the tendency for GDP per capita to grow more rapidly than wages in this period.

For earlier periods, the data on prices and the wage bill from the OECD national accounts are lacking. Maddison (1991), however, does provide data on unemployment and the participation rate. For the large majority of countries in the analysis here, the unemployment rate rose substantially over the period 1920 - 1938, and especially so over the 1930s (obviously). The participation rate, on average, increased somewhat during 1913 - 1938, but fell in most countries during 1938 - 1950. In the interwar period, one thus sees increasing unemployment, and increasing participation rates. The latter trend induces a more equal development between wages and GDP per capita, whereas the former causes GDP per capita to grow relatively slow as compared to the wage rate. Judging from the data in Figure 1, the latter effect has been dominating in the interwar period. One might also expect, however, that an indirect labour market effect of the unemployment rate on wages was strong during this period.

\section{Convergence of real wage levels and GDP per capita}

For the debate on convergence, the pure growth rates of real wages and GDP per capita are not so interesting. Some idea of the level differences between countries is necessary to assess whether or not convergence has taken place. As Maddison and other authors do for GDP, Williamson provides such level comparisons in the form of benchmarks for individual years. Williamson chooses to estimate benchmarks for several years. Although one may argue that more than one benchmark increases accuracy, this method has the disadvantage that it creates breaks in the time series (at points where one switches from one benchmark to the other).

In order to obtain a time series for wages without breaks (other than those already in Williamson's national data), a benchmark value for the year 1985 was taken from Williamson's second Appendix Table A2.3 ('International Real Wages, $100=$ GB Real Wage in 1975'). The value from this table for 1985 was divided by the value for the United States, after which the growth rates of the series for national real wages (as used before) were applied to this benchmark.

This time series is used to calculate the coefficient of variation on a yearly basis, which will be used as the indicator of convergence here. The coefficient of variation was also calculated for the times series of GDP per capita in Maddison (1995), which are in 1990 Geary Khamis dollars. Although the benchmark years for the wage series and the GDP per capita series are thus not equal, this does not have consequences for the coefficient of variation, because this is a relative, 
not absolute indicator of convergence. ${ }^{5}$ The fact that the two benchmark years are not too far apart (in fact, about as close as the data allows) makes the comparison possible. ${ }^{6}$

\section{Figure 2. Convergence in wage levels (thin line) and GDP per capita (thick line) (coefficient of variation)}

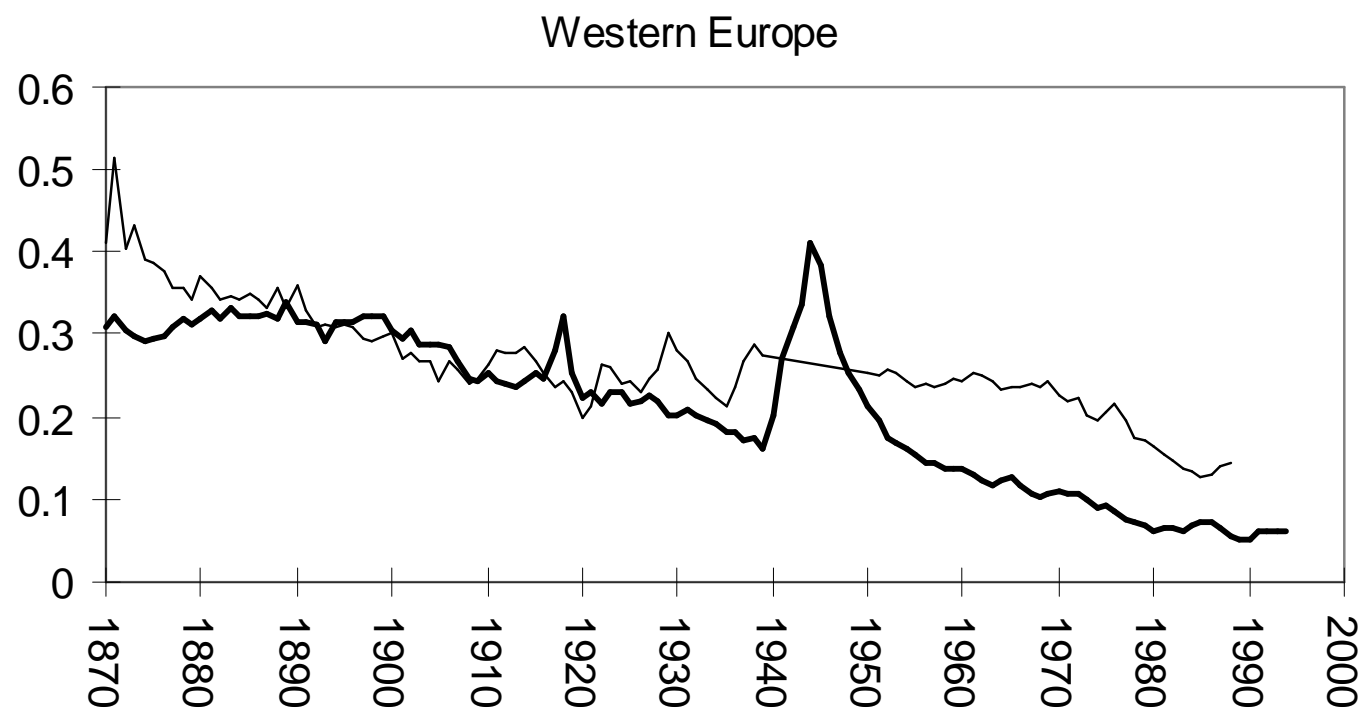

${ }^{5}$ I.e., multiplying the value for our basic indicator (wages of GDP per capita) by a number fixed across countries would not change the value of the coefficient of variation. Hence, even though the GDP and wage series are not measured in similar units, comparing the coefficient of variation between the two is valid.

${ }^{6}$ In light of the fact that there was a large discrepancy in Table 2 between results based on SNA data and results based on Williamson's data, coefficients of variation were also calculated for the limited time span and countries for which SNA data are available. These produced results which were rather close to the results for Williamson's data, so that one may be relatively confident that the convergence trends found in this Section are reliable. 
Figure 2. Convergence in wage levels (thin line) and GDP per capita (thick line) (coefficient of variation) (continued)

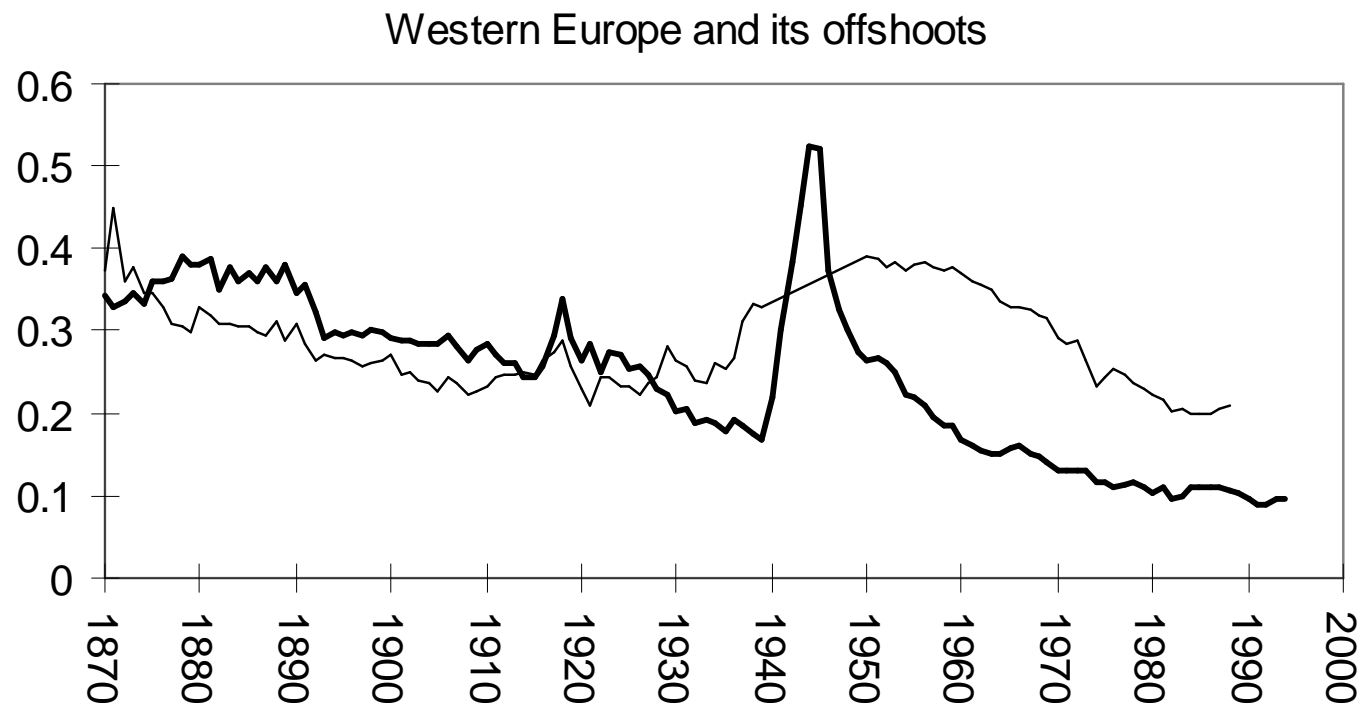

Total Williamson sample

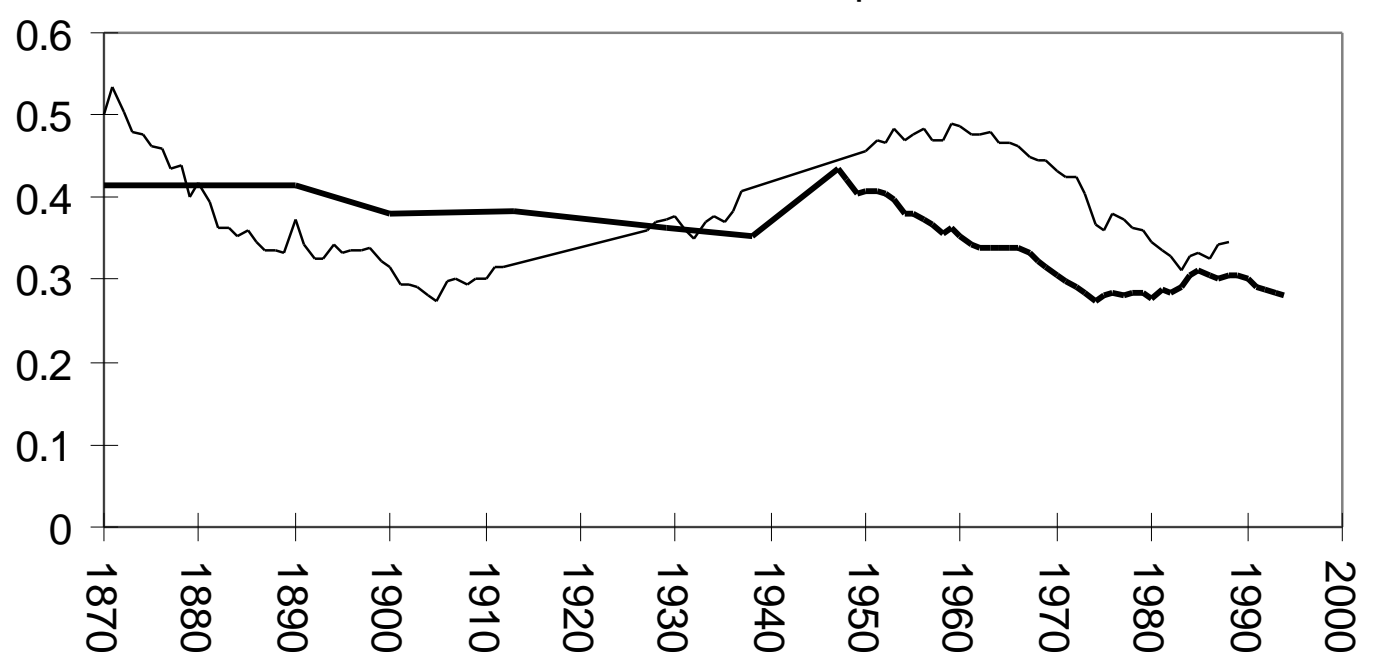

The results of the yearly calculation of the coefficient of variation are displayed in Figure 2 for three different samples of countries. A falling line indicates convergence. The first result in the figures is that the coefficients of variation for wages and GDP per capita are of the same order of magnitude, as could be expected. The differences between the two lines in each graph are particularly small for the period before the second World War. 
For Western Europe, one observes strong convergence for wages in the early years 1870-1890. This essentially entails a fall of the level of dispersion of wages to that of GDP per capita. Disparity in GDP per capita remains essentially constant over 1870-1900, after which slow convergence of both wages and GDP per capita is observed. Convergence for wages stops in the mid-1920s, while GDP per capita shows a converging trend until 1940. After the second World War, GDP per capita converges much more rapidly than wages. In fact, the coefficient of variation for wages remains almost constant over 1950-1970, which is the 'golden age' of convergence in terms of GDP per capita. After 1970, convergence in wages sets in, essentially until the end of the period. GDP per capita convergence slows down, especially after 1980.

Including the Western Offshoots in the picture gives a rather different result. Before 1940, the picture differs not so much from the Western European case, although dispersion in wages and GDP per capita are more similar to each other from the beginning. After 1950, there are large differences compared to Western Europe alone, however. Strong convergence is observed for GDP per capita from the end of the war onwards, while convergence of wages sets in around 1960. During 1960-1980, convergence takes place for both wages and GDP per capita, although the level of dispersion for wages remain quite a bit higher than for GDP per capita.

For the complete Williamson sample (i.e., Western Europe and its Offshoots, Southern Europe, Argentina and Brazil), the trend is more erratic. During 1870-1910, one observes convergence of wage levels, but not of GDP per capita. 1910-1950 shows divergence of wage levels, bringing its coefficient of variation again above the one for GDP per capita (which shows no strong trend). After 1950, strong convergence for GDP per capita sets in, as in the two previous samples. Convergence in wages starts only after 1960, but is particularly strong during 1970-1985. From the mid-1970s onwards, slight divergence in terms of GDP per capita takes place, which implies that towards the end of the period, the lines for wages and GDP per capita are very close to each other.

The literature on convergence has made a distinction between so-called $\beta$-convergence and $\sigma$ convergence. The latter is measured trhough the disparity of GDP per capita (or real wages). The coefficient of variation used so far is an indicator of this type of convergence. Convergence as predicted by the neo-classical growth model is, however, more accurately measured by so-called $\beta$-convergence. This assumes a relationship of the form

$$
\hat{y}=\alpha-\beta \ln y_{0},
$$

where $y$ is GDP per capita (or real wage), the hat indicates a growth rate, and the subscript zero indicates an initial value. $\alpha$ and $\beta$ are parameters which have to be estimated. The above equation assumes unconditional convergence. If a set of conditioning variables (such as savings rates) are included in the equation, $\beta$-convergence does not necessarily imply $\sigma$-convergence. The latter is also the case when the error-term which has to be included for estimation purposes has a relatively large variance. 
Because $\beta$-convergence is the more intuitive measure, and because $\beta$-convergence does not always lead to $\sigma$-convergence, the rates of $\beta$-convergence wre also estimated for the samples and time periods identified so far. The results of this are presented in Table 3.

Table 3. Rates of $\beta$-convergence for real wages and GDP per capita

\author{
Wages \\ GDP per capita
}

(1) All countries

$1870-1913$

$\beta$
-1.265

$1913-1950$

$-1.565$

$1950-1973$

$-0.425$

$-0.4$

$1973-1988$

(2) Western Europe plus offshoots

1870 - 1913

$-1.72$

$-1.407$

$1913-1950$

$-1.907$

$-1.494$

$1973-1988$

(3) Western Europe

$1870-1913$

$-1.522$

$-1.79$

$-1.99$

$-2.283$

$1950-1973$

$1973-1988$

\begin{abstract}
t-stat
\end{abstract}
3.44

2.44

0.55

0.35

$$
6.21
$$

0.98

$-0.664$

$-0.828$

4.77

$-2.938$

$1.02-2.548$

$\begin{array}{ll}5.85 & -0.508\end{array}$

$1.27-1.373$

$3.72-3.353$

3.77
Which converges more rapidly?

wages

wages

GDP

2.68

0.74

2.14

1.2

5.76

1.77

2.36

1.68

5.84

3.34 wages

wages

GDP

GDP

wages

wages

GDP

GDP

The results of the tests for $\beta$-convergence by and large point in the same direction as the $\sigma$ convergence indicators used above. In the pre-1913 period, convergence in real wages and GDP per capita is generally significant. The rate of convergence for wages is higher than for GDP per capita in all three samples. For the interwar period, convergence is most often not significant. Only for the sample as a whole in the case of wages do we find a significant $\beta$. For the period 1950 - 1973, significant $\beta$-convergence is found for both wages and GDP per capita, but the latter shows more rapid convergence in all cases. This result is reproduced for the period after 1973, with the exception of the complete sample. In the latter case, convergence is not significant for wages or GDP per capita.

Summarizing, there are important differences between convergence trends for wages and GDP per capita. While one observes strong convergence for GDP per capita in all three samples after 1950, convergence of wage levels is much less strong. Particularly within Western Europe, convergence of wage levels is almost absent during 1950-1970. Also before the second world war, there are some differences between convergence of wages and GDP per capita. 


\section{Conclusions}

This paper has examined and compared the long-run trends in wages and GDP per capita. The main differences between those two trends emerge in the period after 1950. During 1950-1980, the gap between the level of wages and GDP per capita (both expressed as their value in 1900 set to 100) typically becomes larger, with a tendency for some convergence between the two trends towards the end of the period. In terms of disparity between countries, it is found that the period after 1950 shows strong convergence of levels of GDP per capita between countries, but less strong convergence for wages.

Neoclassical growth theory and trade theory (HOS) both generate predictions for the relation between convergence in wages and convergence in GDP per capita. Growth theory would predict that both variables converge internationally at approximately the same rate. Trade theory predicts stronger and more rapid convergence for wages, compared to aggregate GDP per capita (or rather, labour productivity). Neither of those predictions is substantiated by the findings here, with the exception for the earliest period (1870 - 1913). In the latter case, the pattern is as predicted by the trade theory. In other case, either no convergence is found at all, or wages converge at a slower rate than GDP per capita. Thus, the link between convergence in factor prices and convergence in GDP per capita is more complex than either one of these two theories acknowledges.

More theoretical work on the relation between factor price convergence and convergence in GDP per capita seems to be necessary to explain the findings in this paper. Such a theory would undoubtedly benefit from an explicit focus on the interaction between the two variables (such as in the literature on the link between distribution and growth), and a focus on the institutions of labour markets. These institutions are highly specific to countries, which provides some idea as to why the observed relations between wages and GDP per capita differ widely (with regard to details as well as some of the more general trends) between countries. 


\section{References}

Abramovitz, M. A. (1986), 'Catching Up, Forging Ahead and Falling Behind', Journal of Economic History, 46: 385-406.

Barro, R.J. and X. Sala-i-Martin, 1995, Economic Growth, New York: McGraw Hill.

Dollar, D. and E. N. Wolff (1993). Competitiveness, Convergence and International Specialization. Cambridge MA, MIT Press.

Fagerberg, J. (1994), 'Technology and international differences in growth rates', Journal of Economic Literature, 32: 1147-1175.

Gerschenkron, A. (1962). Economic Backwardness in Historical Perspective. Cambridge MA, Harvard University Press.

Leamer, E. E. (1984). Sources of International Comparative Advantage. Cambridge MA, MIT Press.

Maddison, A. (1991). Dynamic Forces in Capitalist Dvelopment. A Long-Run Comparative View. Oxford, Oxford University Press.

Maddison, A. (1995). Monitoring the World Economy 1820-1992. Paris, OECD Development Centre.

Solow, R. M. (1956), 'A Contribution to the Theory of Economic Growth', Quarterly Journal of Economics, 70: 65-94.

Solow, R. M. (1970). Growth Theory: An Exposition. Oxford, Oxford University Press.

Williamson, J. G. (1995), 'The evolution of global labour markets since 1830: background evidence and hypotheses', Explorations in Economic History, 32: 141-196. 